\title{
BIOPOLITICALLY (UN) CARING: SUSTAINING BODIES AND SHAPING CARE IN PRECARIOUS ENVIRONMENTS
}

MAGDALENA ZEGARRA CHIAPPORI PhD Candidate, Universidad de Michigan, Ann Arbor mzegarra@umich.edu

AвSTRACT: Much of the anthropological literature on care has addressed the topic as an ethical practice encompassing empathy, solidarity, and the capacity to recognize the other as worthy of engagement (Kleinman 2009; Stevenson 2014; Taylor 2008; Aulino 2016). Care relations are, in theory, everyday acts that sustain social ties, social persons, and social reproduction (Buch 2015; Zelizer 2005; Hochschild 2003). But in underprivileged social settings, where care is a scarce resource, can it still be conceived of as a moral practice that sustains social life? Grounded in twenty-four months of field research at an institution for abandoned elderly people in Lima, Peru, this article explores the multiple and sometimes contradictory expectations and understandings that can emerge in relation to providing care in an environment of precariousness, social death, and institutional disregard. My argument is that, at this particular institution, care is offered precariously, to the limits of its capacity, and essentially as a practice of biopolitical control directed at the bodies and lives of the elderly. 
KEYWORDS: biopolitical care; precarity; old age; physical restraint; bodies that matter; bodies that bother.

REsuM: Gran part de la literatura antropològica sobre la cura ha abordat el tema com una pràctica ètica que engloba l'empatia, la solidaritat i la capacitat de reconèixer l'altre com a digne d'atenció i compromís (Kleinman, 2009; Stevenson, 2014; Taylor, 2008; Aulino, 2016). Les relacions de cura són, en teoria, actes quotidians que sustenten els vincles socials, les persones socials i la reproducció social (Buch, 2015; Zelizer, 2005; Hochschild, 2003). Però en entorns socials desfavorits, on la cura és un recurs escàs, podem continuar concebent-la com una pràctica moral que sosté la vida social? A partir de vint-i-quatre mesos de recerca de camp en una institució per a ancians abandonats a Lima, el Perú, aquest article explora les expectatives i comprensions múltiples i a vegades contradictòries que poden sorgir en relació amb la prestació de cures en un entorn de precarietat, mort social i menyspreu institucional. El meu argument és que, en aquesta institució en concret, la cura s'ofereix de manera precària, fins als límits de la seva capacitat i, fonamentalment, com una pràctica de control biopolític dirigida als cossos i les vides dels ancians.

PARAULES CLAU: cura biopolítica; precarietat; tercera edat; restricció física; cossos que importen; cossos que molesten. 


\section{Introduction ${ }^{1}$}

In a couple of hours her Facebook post received more than two thousand "likes". Peruvian actress Manuela Paz was denouncing, through her Facebook account, abuse perpetrated against her childhood nanny, Carmen Bonifaz, who had been living in the La Merced shelter for the past ten years. Before Manuela Paz's social media intervention, La Merced rarely appeared in the news and the average Lima resident was unaware of its existence, despite it being the largest institution in the country offering assistance to elderly people at social risk in later life. Paz was condemning having found her nanny, on one of her mother's visits to the institution, in a deplorable state: in addition to not receiving medication for her dementia, she said that Bonifaz was wearing old rags instead of diapers, was undernourished, and was tied to her bed with cloth ropes that rigidly held her arms ${ }^{2}$. Over the following days, La Merced was visited continuously by several public officials from a number of Peruvian government institutions: the Ministry of Women and Vulnerable Populations, the National Ombudsman, Lima's Municipal Council, the Judiciary, and the Congress. The aim of these visits was to ensure that the institution, now publicly discredited, was implementing the measures urgently required to guarantee the quality of the care provided to its residents. In the meantime, employees concerned for the residents' health and wellbeing expressed their anger and worries. They maintained that, with the little or no resources they received from the institution, it was inevitable that the care given to the residents would be precarious. "We do what we can with what we have. Now we are being judged as heartless people", was their shared response to the situation.

This article explores how care is provided in underprivileged social settings like that of the La Merced shelter. Much of the anthropological literature on care has addressed the topic as an ethical practice encompassing empathy, solidarity, and the capacity to recognize the other as worthy of engagement (Kleinman 2009; Stevenson 2014; Taylor 2008; Aulino 2016). Furthermore, care relations are everyday acts that

I This article was made possible by financial assistance from the Ruth Landes Memorial Fund, a program of the Reed Foundation. 
sustain social ties, social persons, and social reproduction (Buch 2015; Zelizer 2005; Hochschild 2003). But what happens when care as a resource is scarce due to the political-economic arrangements of a specific social setting? Is care still a practice based on solidarity, recognition, and empathy? Can it remain so under constraining material conditions? Does it continue to sustain relationships within the social fabric? Drawing upon twenty-four months of ethnographic fieldwork at the La Merced shelter, I examine the multiple and sometimes contradictory expectations and understandings that can emerge in relation to the provision of care in an environment of poverty and destitution. In the following pages, I argue that, in La Merced, care is offered precariously, to the limits of its capacity, and essentially as a practice of biopolitical control directed at the bodies and lives of the elderly. This article offers a detailed examination of how, at this institution, the bodies of older adult residents are subjected to care procedures that often conceal indifference while ensuring the preservation of physical life. In this place, the body is cared for at the expense of the self, as residents are commonly exposed to uncaring practices designed merely to sustain their bare existence.

\section{Methodology}

This article draws on my doctoral field research conducted with older adults in the La Merced shelter from September 2017 to September 2019. During 24 months of fieldwork, I participated in the rhythms of daily life at this institution by accompanying the older adults throughout their everyday activities; tracking their medical treatment at the shelter's medical unit or at public hospitals; joining them in celebrations, cooking workshops, dance classes; and also providing care to the bedridden (feeding them, taking their blood pressure, and giving them their medication). Moreover, my long-term research involved deep immersion that, in a few cases, gave me the opportunity to accompany certain residents in their deaths. My methodology emphasized face-to-face interactions with both residents and staff from the institution. These included semi-structured interviews and informal conversations. A significant amount of my data also comes from field observations, especially from my interaction with dependent 
and cognitively impaired residents. Taking into account the vulnerability of these older adults, I decided not to interview them (aside from the difficulties this would have entailed, ethically, I did not feel comfortable doing this). Instead, I spent several hours accompanying them, sitting by their side or talking to them. the head nurse of La Merced shelter allowed me to help in providing care in one of the residential wings by performing some tasks, always under supervision.

In addition to these interactions, my methodology also looked at how the recently implemented public policies on old age in Peru are shaping the ways residents of this institution are rendering their aging experience meaningful. Moving from face-to-face meetings between residents and staff of the institution to the macro-level of incipient public policies implemented by the Peruvian government to ensure people age with rights and dignity allows us to discern the social background in which the elderly in Peru are facing the economic and political challenges of growing old in marginalization and neglect.

My presence at the institution was well-received by the residents, as many showed great interested in talking to me and telling me their lifestories. While I did not get written informed consent from them all, I carefully explained to all participants that I was an anthropology doctoral student interested in the ways in which they grew old in the face of family abandonment, social marginality, and precarious care. All of my informants were specifically asked if they wanted to be part of my study, and they agreed eagerly. Staff, on the other hand, were more distant at the beginning. As many of them told me later in the study, they perceived my presence as a threat as they thought the institution had brought me into the shelter to keep a close eye on their job performance. With time and through several interactions, it became clear to them that I was not a "spy" that La Merced had hired to constantly monitor the quality of their work. 


\section{Multiple epistemologies of care}

In Care in Practice (2010), Anne Marie Mol et alii argue that the topic of care has still not been given enough scholarly attention, despite the fact that care practices sustain many of the processes of everyday life. While this argument is valid, in recent years, the field of anthropology has produced a comprehensive body of work focused upon the issue of care. Evidence from various anthropological sites (Livingston 2003; Aulino 2016; Buch 2013, 2015; Mol 2010) shows how care is a resource that touches on the intimate and familial, as well as the economic and the political. Hence, care cannot be understood from one single perspective, rather it can only be defined by taking into account the multiple specificities of local contexts and their respective moral, political, and economic circumstances. It is contextual and specific, a polysemic concept emerging from the connections between macroforces and microprocesses (Buch 2015).

In a moving essay, Arthur Kleinman describes caregiving as a (tiring) moral practice, a kind and loving engagement with other human beings that makes both the caregiver and the care receiver more human, since the experience allows them to recognize each other. Hence, care "is a practice of emphatic imagination, responsibility, witnessing, and solidarity with those in great need" (2008: 293). The power of Kleinman's description lies in the fact that he understands care as a difficult intersubjective process encompassing the recognition of the others' subjectivity, despite the fact that the person he is caring for (his wife) is suffering from dementia. Scholarship focused on care and dementia consistently emphasizes the importance of acknowledging the ill person's presence and shows how, while it is common to think of people with Alzheimer's as gone and forever lost, studies on care in these contexts reinforce this assertion by showing how dementia sufferers continue to engage in caregiving practices with those close to them (Taylor 2008). In a similarly personal article in which she reflects on her mother's Alzheimer's, Janelle Taylor shows us that, despite undergoing cognitive loss, her mother still preserves the capacity to care for her, her child. In this sense, care is not merely a unidirectional practice in which only the caregiver looks after the ill person, but rather a transformative process in which two (or more) persons render the other 
valuable and meaningful. Equating care with recognition, it is through this process that Taylor's mother and Kleinman's wife are not simply old bodies, rather they are individuals who continue to participate in the social world and thus retain a place within it, because, by these loving acts, they are made visible. Under such conditions, care is about building sociality, emotionally investing in human relationships by paying attention to the welfare of others (Zelizer 2005).

As a multidimensional concept, however, care not only comprises the intimate and the affective. Anthropology addresses it rather as a complex, layered set of practices embedded in relationships of power ${ }^{3}$, identity and morality (Brijnath 2014). We can add that care practices are also shaped by the constitution of state bureaucracies, the configuration of global processes such as migration, the circulation of money, and the ways in which gender roles are structured in our current societies, societies where women's reproductive labor is mostly invisible and does not have a reciprocal nature (Comas d' Argemir 2017; Aguilar, Soronellas, and Alonso 2017).

Recent anthropological work also emphasizes that care entails, under specific circumstances, a (bio)political engagement (Stevenson 2014). In some contexts, care is a form of governmentality: a procedure of social control embedded in institutions that continually monitor and manage the lives of those they claim to be caring for (Stevenson 2014: 5). In this way, care is used as a powerful device that is, paradoxically, uncaring (Biehl 2012). This care is anonymous, bureaucratic, and administered indifferently, without regard for the identity of the individual receiving the care. It is intended only to ensure the person's continued survival. Such care is eminently political, used to exercise surveillance over bodies and subjects obliged to comply with a dominant system that may even seek to justify inhumane actions against them. In this context, care becomes a mechanism for oppression and subjugation of those who are different. To care means to exercise domination over the bodies of those deemed inferior, uncivilized, or unwanted, but who must be kept alive,

3 In the particular context of this research, the specific social axes in which these relationships of power are made evident are social class, ethnicity, gender, physical impairment, cognitive decline, and age. 
nevertheless. Under such circumstances, care may disguise murderous activities in which people's subjectivities, individualities, and humanity are rendered worthless. In such a context, care becomes a scarce resource and individuals are exposed to what anthropologist Joao Biehl calls "social abandonment" - the disregarding of those who are most vulnerable. His ethnography of the geriatric institution Vita shows how people are neglected rather than cared for at this center, through measures such as providing inadequate psychiatric medication. Providing the same drugs to persons with different health requirements is an example of the standardization of care, and the specific needs of those being cared for go unrecognized. What is actually not being acknowledged is exactly who the person in need is. This disregard for the individual is apparent in the way that, in all institutions like Vita, "the inmate is excluded from knowledge of the decisions taken regarding his fate (Goffman 1961: 9). Essentially, institutions take care of others because, as bureaucratic mechanisms, that is what they are expected to do. Consequently, these forms of care are precarious and defective: "certain technologies that are named or fall under the category of 'care' [...] actually create the conditions for the possibility of evil, precisely because they are not care [...]" (Biehl 2012: 251). Instead of building sociality and reproducing/sustaining social life, health care systems in the poorest parts of the world continue to kill people through disregard for those in need. What Biehl's ethnography tragically shows us are the limits of care in poor countries, where people fall through the cracks of structures that allow them to die both physically and socially. Therefore, disregard is disguised as care. Within a political order and an economic regime that encourages these kinds of amoral practices, individuals are no longer considered as human beings, as citizens with rights and dignity, but rather as what Agamben (1998) calls the "ex-human": the marginal, the outcast, the forgotten and undesirable. Moral bonds and worlds are disrupted.

Exploring care analytically and situationally is important because certain caring, or uncaring, practices offer us insight into the marginalized conditions with which many social groups struggle. Being disregarded, neglected, or abandoned in today's world is a by-product of unequal social 
bonds and relationships, many of which are a consequence of systems founded on exploitation, broken family bonds, economic instability, and dehumanizing governmental policies. Care can reveal much about the dramatic configuration of the contemporary world system. This system, under global capitalism, reproduces the hegemony of one group of people over another, so that some lives matter more than others. In today's world, many people experience lives oppressed by public policies and structural forces that condemn them to social invisibility. In this article I am concerned precisely with the ways in which a highly vulnerable sector of the Peruvian population is provided with care in an environment where the political-economic context constrains individuals' possibilities to live well, to age well and, ultimately, to die well.

\section{Growing old in Lima, Peru}

In Peru, increasing numbers of people are entering old age in conditions of extreme poverty, and exposed to ever-increasing social disparities. From the 1960s to the 1980s, Peru underwent a rapid process of urban migration through which rural settlers from the Andes relocated to the outskirts of Lima. With Lima's rise in population (Lobo 1982; Matos Mar 1984), many migrants found themselves working informally, as the formal job market was unable to keep pace with the demands of a rapidly increasing population. Throughout the 1980s and 1990s, social and political crises deepened in the face of hyperinflation, extreme political violence, and corruption. As in much of the rest of Latin America, the fragility of the socio-political order was exacerbated by the introduction of neoliberal policies designed to limit state responsibility for social programs (Roberts 2012), trapping migrants and Lima's urban poor in insolvency, with limited or no access to pensions and social benefits to support them in their old age.

In Peru, the elderly comprises $10.4 \%$ of the total population (INEI 2018). In the Peruvian capital, there are approximately 1100 abandoned elderly citizens (abandoned by both their families and the State) (Ortiz 2013), many of whom live in homes for the aged like La Merced, a dilapidated facility lacking the financial resources to provide appropriate 
care for its residents. Currently, Peru is facing demographic transitions that constitute a challenge to its public institutions, while the State is slowly implementing government-led mechanisms to address the pressing needs of this section of the population. Since 2002, the Peruvian government has announced many proposals aimed at protecting the rights to age with dignity of elderly men and women who have been neglected by the State and abandoned by their families. In 2002, the Ministry for Women and Social Development (now the Ministry for Women and Vulnerable Populations) announced the First National Plan for Older Adults (PLANPAM). In 2006, the Peruvian State approved the reformulation of this first PLANPAM initiative and extended its validity through the period 2006-2010. This document clearly stated that one of its main aims was to improve the life quality among the elderly population, and promote their integral development to give people opportunities for a healthy old age, and a dignified and independent life within their families and communities (PLANPAM 2006-2010: 18). However, because adjusting these national policies involved overcoming numerous obstacles in the most marginalized parts of the country, new intervention strategies were introduced as part of PLANPAM 2013-2017 (Blouin 2018). This last document identified several of the challenges and difficulties faced by older adults in Peru; however, the report did not make a comprehensive diagnosis of the current national situation of this population. In 2016, Congress issued Law 30490 (Ley del Adulto Mayor, in Spanish) and in August of 2018, the regulations underpinning the law were approved. The Peruvian State intended it to be a broad and complete response to the urgent political, social, and economic needs of the elderly; however, Law 30490 and its regulations have several aspects that are inconsistent with the Peruvian national reality. Experts in public policies in the country told me that, while the promulgation of Law 30490 was an important social achievement, it did not seem to take into consideration the multiple precarious realities that a large number of older adults in the country must endure, including poor retirement pensions, lack of health insurance and social security, weak family networks, and inadequate housing, among others. As a result, this legal instrument is 
inadequate for guaranteeing that the elderly who live in marginalized environments (dilapidated public or private institutions throughout the country, poor neighborhoods, shantytowns, rural communities, or homes for the elderly that function without proper licenses) will have their many pressing needs met. Clearly, efforts to ensure coherent and effective institutional policies for the protection of the vulnerable elderly in Peru remain deficient and uncoordinated, despite the fact that the country has implemented a normative framework through protocols, laws, and legislative decrees. This has highlighted the challenges posed by the extremely rapid rise in the ageing population of a country with poor material and social infrastructures. It can be seen at a macro level throughout Peru (in the weak health care system, for example), and also at a micro level (in a residential institution such as La Merced).

La Merced currently houses $335^{4}$ elderly adults who come from the most marginalized sectors of Lima. These 335 people comprise a significant $34 \%$ of the total population of abandoned older adults in Lima, making this shelter the largest institution in the country offering assistance to men and women experiencing economic scarcity and social risk in old age. La Merced falls under the category of a "mixed" residential institution, according to the regulations of Law 30490: it has both an independent and self-sufficient population, and one with geriatric needs. The majority of those living there do not have active kin ties, as many never married nor have a family of their own. Others still preserve family bonds but reside at the facility because their families cannot or do not want to look after them. The severed kin ties and poor institutional assistance prevalent at La Merced make it an emblematic zone of social abandonment (Biehl 2005). Moreover, representing the many social microcosms of Lima, La Merced constitutes a prime example of what Goffman (1961) called a "total institution": a place of residence where a large number of like-situated individuals, cut off from the wider society, conduct all their everyday activities.

4 The number of residents at La Merced varied considerably. At the time this article was written, the total number of residents was 335; however, numbers fluctuated considerably, reflecting the deaths recorded, as well as new admissions to the institution. 
The main care providers at La Merced are mainly women nurse technicians, especially for the physically or cognitively impaired residents. Their responsibilities include waking up the residents and putting them back to bed at night, bathing them, dressing them, giving them their medication, feeding them, changing their diapers, and rotating them in bed to prevent bedsores. The age of these women varied from the late twenties to early sixties, depending on how many years they had been working at La Merced. Among the youngest, I found that the majority of them had graduated from nursing schools whose programs quite often did not meet the standards of The National Superintendence of Higher University Education, the Peruvian public entity responsible for securing the quality and accreditation of higher educational institutions, such as universities and professional institutes. With a poor education and, at the same time, the work-related invisibility of La Merced, these women's salaries were very low. They barely reached 930 soles a month (around 220 euros) for a six-hour workday, six times a week. The majority of them came from the lower socioeconomic sectors of the capital city, and many of them were single mothers themselves or daughters who had to look after their own parents or grandparents. As many of them told me, this, together with their poor salaries, made them feel exploited by the institution.

For me, after six months doing fieldwork at the La Merced shelter with its elderly residents and staff members, the case of the young actress and her nanny was merely the tip of the iceberg. This unfortunate event was reported by the media, but I had already witnessed other "irregularities" in relation to the care being provided to the residents of La Merced. None of them were reported in local news or social media, but they were no less worthy of urgent attention, and no less disturbing in nature. Admittedly, it was true that La Merced lacked several resources required for providing what might be classified as "good" or "efficient" care: there were shortages in medication supplies; nurses and nursing technicians were unable to cope with the workload due to staff shortages; and the infrastructure of the facility was severely run-down. Under such circumstances, in the midst of precariousness, scarcity, and uncertainty, how could this institution guarantee its residents adequate care? How could it look after them as human beings and not as anonymous selves? 


\section{"It's for their own good": (Un)caring but sustaining practices of care}

I first met Saturnino when I helped some members of the staff move him in bed as he was a bedridden resident. During that first encounter, I was struck by his gaze: it was as if his silent eyes were asking for something nobody was able to hear. The second time I met him, I had been asked by the staff to feed him, as the institution was short of staff, and time was in equally short supply. As spoonfuls of food came and went, I noticed that his wrists were tied to the bed with some kind of cloth ropes that restrained him from moving. Later that day, I asked one of the nursing technicians why Saturnino was tied in that way. She told me that it was a security measure; otherwise, he might fall from the bed, rip out his nasogastric feeding tube, or handle his own feces. The woman finished her explanation with conviction: "It is for his own good. I have to take care of him".

Physical restraint has long been debated in bioethics and nursing literature and, while today there are some claims that it must only be used under strict and specific circumstances, the use of this procedure when working with older adults and patients suffering dementia and impairment remains highly controversial (Rafiee 2009; Saarnio and Isola 2010). Physical restraint has been defined in different ways, but the general consensus is that it implies a restriction in movement and freedom for the person being cared for (Øye, Jakobsen, and Mekki 2016; Goethals, Dierckx de Casterlé, and Gastmans 2013; Hamers and Huizing 2005). This justification for using this method lies in the fact that patients can be dangerous to themselves and to others. In order to prevent injury, aggression, wandering, and to allow medical treatment without disruption and resistance, some health providers see physical restraint as the most viable option for managing individuals' bodies and lives (Øye, Jakobsen, and Mekki 2016). When I asked in La Merced why people were tied down (amarrados - the colloquial term that everybody at the institution used to refer to this practice) I was constantly told that this was the most effective security measure in a context of deep material scarcity ${ }^{5}$. Precariousness

5 Nursing technicians, nurses and other health workers told me constantly that if a bigger budget 
and lack of resources were, then, a key factor for understanding how relations of assistance and aid were shaped in this setting.

Saturnino spent his days and nights lying in an old clinical bed in Ward B of the La Merced shelter. This area of the institution was set aside for bedridden and wheelchair bound residents who could no longer take care of themselves and whose physical and cognitive capacities were seriously compromised. These individuals were deemed by the institution to be "totally dependent residents", requiring assistance in all their daily needs (in other words, their subsistence depended on the care they were given by staff). As one of the most forgotten wards at La Merced, Saturnino's room displayed many signs of material deterioration: cracked floors, peeled and filthy walls, a broken sink for personal use, and moth-eaten curtains. His room was on the second floor, next to a reeking bathroom. I soon came to learn that Saturnino was not the only person tied to their bed, and that other totally dependent residents spent their days in similar circumstances.

"Tying people up" in La Merced meant investing time and energy in guaranteeing fragile residents' bodies were kept safe. A casual conversation with one of the nursing technicians was what led me to understand how care is conceived at La Merced by those responsible for providing it. To my naïve question of whether or not she had conflictive feelings about practicing such methods, the woman told me: "I must tie them up. Otherwise, I'm being irresponsible. I do what is best for them, even if newcomers like you don't understand why we do this. It's the only alternative we have, given the staff shortages. It would be impossible for one of us to spend all day by their bedside watching over them. There's no money for that". Undoubtedly, it is lack of resources that defines the nature of care at La Merced. Materiality and scarcity, therefore, are key factors in any understanding of how care is shaped by social vulnerability.

\footnotetext{
had been available to meet the care needs of the residents, the shelter would have been able to hire more staff. This would mean that the nursing technicians would have fewer patients under their care, and would therefore have more time to spend with their patients. Under such conditions, it would not be necessary to restrain the residents. This practice is employed because there are not enough staff members on duty to ensure that accidents are prevented. If more staff were hired, the nursepatient ratio in Ward B could be reduced from 1-10 to 1-5, which would have an enormous impact on the care offered to patients.
} 
Residents at La Merced are not just tied to their beds; those who remain in their wheelchairs are also tied down, their torso secured to the back of the chair. Many of the residents who retained cognitive capability (although with many limitations) complained to me that these measures restricted them in the few activities they could manage, such as eating by themselves, and told me they considered the practice abusive but inescapable. As the days passed, I witnessed not only residents being tied to their beds and wheelchairs, but also how staff controlled aspects of the residents' physical selves without their consent in the name of maintaining basic health standards: beards were shaved, hair was cut, eyebrows trimmed, nails clipped, even when residents refused and expressed their wish to adhere to their own personal preferences. My observations led me to conclude that the residents' bodies were being strictly monitored, regulated, managed, and disciplined through a range of procedures conducted in the name of sustained "good health" and "safety". I soon came to understand that within the institution, care was seen as the practicing of biopolitical control designed to ensure the continuity of these people's bodies in the here and now and the preservation of their physical life. Through the use of improvised resources such as rags for securing limbs to beds, staff worked under the imperative of ruling out the possibility of residents hitting their heads, slipping on the floor, becoming aggressive, or hurting themselves and others.

At La Merced, the subsistence of bodies is an imperative. This is achieved through procedures perceived as care practices, of which tying individuals to beds and wheelchairs is just one example. In Ward B, every morning, residents are woken at 5.30 am. After being bathed and dressed, they are all brought to the main hall of the ward, where wheelchairs are "parked". Throughout my 24 months of field research, I witnessed how the fully dependent residents were placed, day after day, month after month, in the same corner of this hall, in front of the same table, next to the same people, from 6 am to $4.30 \mathrm{pm}$. On more than one occasion, I attempted to take residents to their rooms because they told me they got bored doing nothing in the same area of the ward, where they received 
no kind of stimulation from staff 6 . And on more than one occasion, I was told by staff that I could not take residents to their rooms. The reason? They could fall from their wheelchairs and therefore be at serious risk. If something happened, staff would be held responsible. It was clear to me that, by "caring" for residents, staff were protecting themselves. Bodies had to be supervised. Furthermore, lives, at the end, were subject to strict surveillance. The bodies and lives of these dependent elders mattered. Because they mattered, these bodies were monitored: it was important to know what they were doing, how they were spending their time, which spaces and areas they were occupying, and whether or not they might be "misbehaving" (by rummaging in their diapers, loosening their restraints, or masturbating in public). Fully dependent residents' lives, wishes, desires, and expectations were all carefully controlled, like the inmates of a panopticon. Old people told me often that they felt trapped, stripped of the ability to make minor choices regarding their life styles or daily routines. Their agency was obliterated as "care" practices concealed systematic indifference, mistreatment and even violence against the most vulnerable, those who had no say in how they wanted to spend their days at the institution. Ultimately, care at La Merced was configured as a form of management and control of residents' bodies and lives; it was a way of governing their conduct and their everyday (Foucault 1976). Under the guise of offering "care", La Merced, as a total institution, constrained and managed these men's and women's independence, denying them the status of free individuals and defining them as a population of anonymous bodies and existences that needed to be fed, bathed, dressed, and sustained in space and time. They were merely a conglomerate of old

6 At La Merced there is an Occupational Therapy unit offering activities to several residents in a range of physical and cognitive conditions. Many residents visit this area. On occasion, the Occupational Therapy team also visited some of the wards where patients were in a condition of dependence. However, during my entire time at the institution, I never saw the team visit Ward B. It should be noted that the decision to visit, or not to visit, the ward was not made directly by the Occupational Therapy team. From what I was able to gather by talking with the workers, these instructions came from higher up. In this context, even if the unit supervisor considered that it would be good to visit these patients, he could make no decision in that regard. Consequently, the patients in Ward B did not receive any type of stimulation. Some nursing technicians who worked in the ward in question would approach the residents for brief periods, speak with them occasionally, or pass them something, but such actions were few and far between. 
decrepit bodies. The institutional mandate was that they must survive, regardless of how and under what conditions. Thus, in a place like La Merced, bare life becomes the overriding goal. Individuals only count in terms of the preservation of physiological life, while those same lives lack all political and social significance. Tied to their beds, shaved against their will, the "subject" being cared for is actually merely an object of care. These individuals' bodies matter as worth-governing entities, while their subjectivity is entirely neglected.

The subsistence of the bodies and lives of those residents was conducted via what I call uncaring but sustaining care practices. I understand uncaring but sustaining care practices as everyday institutional procedures (feeding, changing diapers, healing wounds, providing medication, bathing, dressing, measuring blood pressure, etc.) conducted in a timely and consistent manner with the aim of extending residents' bare survival, while at the same time disregarding their status as unique individuals, as people with their own inner worlds and expectations who should have a say in how they want to age and what kind of care they want to receive. In the majority of cases, when assistance was provided to dependent residents, the methods employed were harsh and rough, lacking in consideration and gentleness ${ }^{7}$. Tactless as they are, such care practices can be measured, quantified, and evaluated. For example, if an elderly person survives pneumonia, against all odds, care is deemed efficient. This is a dimension of care that is tangible and observable, mostly through the reports produced by the staff. Feeding residents, bathing them, changing their diapers, turning their bodies to prevent bedsores, dressing and undressing them, all of these routine daily practices were carried out when required, albeit not always effectively. But the ways in which these acts were performed revealed a lack of attentiveness and kindness, as well as a high degree of standardization. Unfortunately, standardization is the modus operandi at the La Merced shelter, where

7 It was common in Ward B for treatment to be provided in an impersonal and neglectful manner. However, it is also important to note that some nursing technicians carried out their work with dedication and conscientiousness. Although in general the care offered to residents by the institution was mechanical in nature, I believe it is important to acknowledge the valuable work being done by some of the nursing technicians. 
resources are insufficient to satisfy the needs of the vulnerable residents who depend on the care the institution provides them.

Everyday practices like those described above are performed mechanically, often without addressing the person being cared for as an individual. On many occasions, I observed how residents were fed quickly by giving them large spoonfuls of food which they found difficult to swallow, and I saw how elderly people were put to bed in dirty clothes ${ }^{8}$. These were common practices among nursing technicians and the result of staff shortages, job dissatisfaction, and a lack of sufficient time to fulfill their duties ${ }^{9}$. Care was offered in an impersonal way, enacted automatically without concern for the individual. This kind of vertical care shows how in our current world, there are many delicadezas humanas que no existen, that is, there is an absence of human tact and delicacy. Bodies come to matter, but the subjective dimensions of the lives contained in those bodies are not considered: life stories, personal histories, and the way the elderly individual seeks to render their aging experience meaningful, are irrelevant when the ultimate goal is to ensure the physical survival of these people. It is as if individualities, who the patient is and what he or she requires specifically in order to achieve a state of physical and emotional wellbeing, are lost in the anonymity of systematic institutionalization, leading to the erasure of names, identities, and individual needs. The verticality of such care is epitomized by the act of restraining residents' arms and legs to prevent so-called self-harm. While the "what" of the care equation is, to an extent, being addressed (What do dependent residents need in order to remain alive?), the "how" remains unaddressed (How can those needs be fulfilled?).

8 In this situation, I witnessed how a nursing technician put a patient to bed after their meal. The resident had only just eaten and had food residues on his clothing, but this was ignored by the nursing technician, who put him to bed regardless of what he was wearing.

9 The situation of staff at the institution is complex. The nursing technicians are those who are in constant close contact with the residents, and who have a much greater workload. This type of work demands a lot from them physically and emotionally, but, as many have told me, the institution does not take this into account when it comes to their remuneration. Residents find themselves in a vulnerable situation, but so do these female caregivers. Their employment situation is uncertain and in addition a number of them are single mothers with complex family lives. Too often the fact that caregiving is a poorly-paid and socially undervalued occupation means that the tasks associated with the job are not performed as well as they ought to be. 
Of course, care implies social and human relations between staff and residents, but these relations are flawed: individuals in need are not acknowledged and those who provide care exercise power over them. Staff believe they are doing what is best for the elderly residents with the resources they have available in order to keep them alive (that is, prevent their deaths), and in this exercise they conceive of themselves as moral individuals. Thus, relations between staff and residents can be defined as relations of power. As Clotilde, an 86-year-old lady told me, "We are at the mercy of who our caregiver is and how she feels that day. If she is pissed off because she had a problem with her husband before coming to work, she will get even with us". Those in charge of providing care and assistance are, quite often, trampling over the desires, life expectations, and, worse still, rights and citizenship of those persons deemed incapable of looking after themselves. Such transgressions occur in response to the institutional imperative of enforcing life even at the expense of poor individual treatment. Relationships between residents and staff are asymmetrical. Staff, through the "care" they provide, have the power to determine how long residents will live, and how they will age and die.

As power is exercised over them, residents' bodies become the territory of dominance and of bureaucratic administration. But my observations also revealed that not all bodies at La Merced are considered in the same way. In fact, several of these bodies did not matter but actually bothered. Care was inattentive as bodies were seen as workload. I cannot help recalling Saturnino and the many other individuals trapped in the monotony of their beds and wheelchairs to which they were often physically tied. Just like Saturnino, many other bedridden residents lie in old beds unequipped with sufficient ergonomic support. The pressure on their limbs, back, and torso from the mattress and the fact that they are not turned often enough leaves their skin with severe ulcers ${ }^{10}$. After just a few days, bedsores start to appear and the pain, as I was told by staff

10 Once again, it should be noted that, while not all the nursing technicians comply strictly with the protocol, ensuring patients who are bedridden are turned at regular intervals, some of them do comply with these requirements on a routine basis. In this context, the type of care that a resident receives at La Merced depends a great deal upon who the caregiver is, and upon their individual disposition. While some staff members took their duties lightly, others were diligent and highly responsible in their approach to their work. 
and residents, becomes unbearable. In their fragile state, these bodies are seen as problematic: they demand more attention, more investment in terms of care when resources are already pushed to the limits. La Merced is short of staff: in Ward B, two nursing technicians are responsible for a total of twenty residents, that is, ten each. With their workload and poor salaries, nursing technicians and other staff end up disregarding the frailest individuals. On a number of occasions, I overheard nursing technicians addressing totally dependent residents as burdens that delayed them in the countless tasks they had to perform during an average working day. The care required by these residents was seen as a burden and obstacle preventing nursing technicians from completing their duties on time: investing considerable time with these individuals was annoying and upsetting for them, and staff members were tired of satisfying residents' demands. Clearly, such care practices do not address the individual needs of the comatose, of the mute, of those incapable of articulating thought and word. Bedridden, senile and dying residents' bodies are transformed into absent presences occupying the status of the unimportant.

\section{When precarious care is the best choice}

In anthropology, the concept of precarity has emerged as a way of describing the unstable and uncertain conditions in which a vast group of the world's population lives: the elderly, the poor, and immigrants, for example. Such people live at risk, dispossessed, falling through the cracks of a neoliberal economy that does not acknowledge them. As Clara Han has stated (quoting Judith Butler), one aspect of this concept addresses "a common ontological condition of exposure and interdependency that seems to be independent of forms of life" (Han 2018: 332). Human existence relies on connection, and the fact that our lives can be placed in the hands of others (the fact that we are defined through relationships) places us as human beings in a position of profound vulnerability (Butler 2009). This is precisely what the elderly women and men in La Merced experience under the precarious care provided by nursing technicians and staff: vulnerability and incomprehension as they found that their lives 
were at the mercy of caregivers' moods and goodwill, their professional skills, humanity, and empathy, or lack of those traits.

AtLaMerced,careis precarious. Locatedinoneof themostimpoverished districts of the Peruvian capital, the institution is collapsing as resources, including medical supplies, food provisions, personnel, and even time to perform daily duties, become even more scarce. Within its walls, it is not uncommon to see the people who inhabit this place, residents and staff, adopting creative ways of simply getting by: intravenous drips cleverly improvised using Coca-Cola bottles, wheelchairs made from plastic chairs and bicycle wheels, and laundry trays being used when bathrooms are out of order are just a few of the examples of the "survival technologies" being employed. I witnessed multiple and unthinkable ways in which people contrived methods for enduring everyday life within the institution, with its unimagined complications and unfathomable challenges for achieving the goal of ageing with dignity. Scarcity is, of course, a direct consequence of the shelter's low budget, which in turn is the result of poor administration of funds, limited financial aid from the public entities responsible for providing support, and what many of the elderly residents have called repartija, the process by which higher level employees and staff in positions of power illegally appropriate institutional funds, thus divesting La Merced of funds allocated to priority needs such as food supplies or medicines for residents. In such a scenario, what forms of care or quality of life are possible, and can we truly say that precarious care is better than nothing?

I met Carmen Bonifaz in early February. A small, thin woman, she lived in Ward B of the institution and suffered from Alzheimer's, as well as severely reduced mobility. She spent most of her days in her wheelchair, "parked" in the hall of the facility in the company of another fifteen residents who were also suffering from symptoms of senility. At other times, she lay in her bed in her small hospital-like room. Whether she was in her room or the hall, she was always tied down and the complaints she voiced against her suffering were a lament to which staff had become accustomed. On the few occasions I sat with Carmen, she spent her mornings crying and sobbing, claiming she wanted to "go 
home", and "escape this place". "It's time to go. Now. It's time. I don't want to be here anymore", she told me as I sat by her side. In an attempt to soothe her, I asked her why she was feeling so sad. She told me she didn't like it at La Merced. The "señoritas" (the common form of address for the nursing technicians, literally "young ladies" in Spanish) ignored her when she asked them for something. She was invisible and knowing that was the cause of her emotional distress and personal discomfort. Over time, I came to think of her yelling not as a death cry but as a demand for acknowledgement of her life. Often ignored, she wanted to be cared for in a way that addressed her needs as an individual. This happened only on rare occasions, but even this imperfect acknowledgement was far better than not having the opportunity to grow old in an institution, however dilapidated. Most of the time she was seen by staff members as a body that bothered. Nevertheless, she was not condemned to absolute abandonment. By finding shelter at La Merced, she was, to some degree, at least protected and secure: she had a roof and a bed, she was fed, and was often given some medication for her illnesses, whenever the medication was available. With this bare minimum, she could retain a modicum of dignity and humanity: she would be moderately clean and comfortable, and would not experience hunger or die alone in some filthy corner of the city. Given the ambiguous nature of the care with which she was being provided, Carmen's struggle to remain human was filled with conflicting moments, demonstrating that care cannot be defined in absolute terms. Resident's physical lives are preserved and sustained at the expense of their being transformed into "ex-humans" (Biehl 2012) or "homo sacer" (Agamben 1998). However, imperfect as it is, having this alternative is better than nothing, and so care at La Merced is a contested practice. These individuals did not foresee ending their days residing in a total institution, but at least they are able to solve everyday problems such as getting something to eat or a place to sleep. Practical but important issues of everyday life are resolved by living in a precarious shelter and receiving flawed care. Unexpected and fleeting moments of recognition and assistance constitute instants during which some degree of human dignity is preserved, and residents take refuge in this. As precarious as 
this situation might be, it is much better than nothing, and for many it represents their only hope of not becoming totally divorced from humanity. But still, due to the precarity of her circumstance, individuals like Carmen find themselves trapped between the acceptance of flawed caregiving, and their unwillingness to embrace their own social death.

\section{Conclusion}

In this article, I show how, in a materially and socially broken world, care forces us to grapple with countless barriers and difficulties in the quest to provide relief and assistance: limited budgets, the goodwill or ill-will of care-givers, the progressive physical decay and intellectual impairment of the elderly and their friendly or hostile behavior towards others, unmet material needs, filthy environments, institutional corruption, the genuine motivations to do good and the lack of possible ways of pursuing these motivations, etc. As a consequence, care becomes a struggle within a fractured system, whether it be a local system like that of La Merced, or a larger, more complex one like the Peruvian health care system. This fractured system may at least manage to address the biological needs of people to a certain extent, but it fails to address their emotional needs. As I show in my research, as a process, care does not necessarily guarantee wellbeing. On the contrary, care offered under conditions like those I have described can be barely life-sustaining, providing residents like those of La Merced with food, shelter, and medications, but failing to acknowledge their individuality, subjectivity, until their humanity is annihilated. In an underprivileged social milieu, care for the body is provided at the expense of the person and at the same time the bodies that the staff attend are subjected to mistreatment and neglect. The treatment of bodies, illnesses, and physical decay is not enough to enable those being treated to feel they are receiving an appropriate kind of care. Precarious care is far better than nothing, certainly; however, an inability to sense the moods, wills, desires, expectations, or even frustrations of residents who are provided only with biopolitical assistance ignores the fact that those receiving such care do not wish to be seen only as ill or old bodies. They need to be seen as people, as individuals who have lived 
unique lives and who retain expectations regarding how they want to age and die. Disregard for the emotions and the subjective world of the old and the ill leads to uncaring, mechanized, routinized, and standardized ways of providing assistance to those in need, regardless of the fact that they may be given a warm meal every evening or a bed at night, which is La Merced's best case scenario. Only by acknowledging both material precarity and the inner worlds of those who require assistance, as well as their right to visibility within a social milieu so ready to dismiss them, can the first steps be taken towards providing care no longer in biopolitical terms, but as a humane, restorative, and tactful gesture that returns political significance and social importance to those disenfranchised.

It is important to note that those who are politically disenfranchised in precarious care settings such as La Merced are not only limited to the people who receive care. In this center, institutional precarity also affects those responsible for providing and guaranteeing care, who are invisible and vulnerable in the workplace. While they lack salaries and benefits that truly acknowledge the value of the work they do, materially unstable environments also pose a challenge for caregivers who, in most cases, are exploited as workers and must provide assistance in the midst of exhaustion, mistreatment by residents, problematic family environments, and shortage of medical resources. Often, dehumanized, standardized, and mechanical provision of care is not only due to a potential lack of sensitivity on the part of staff. While this is a factor identified in some interactions between caregivers and patients in La Merced, it is also important to understand that care processes do not occur in a vacuum, but are shaped within specific material contexts that certainly have a major impact on the ways in which care is implemented, managed and delivered. The reasons behind inattentive, detached, and merely biopolitical care are not always the product of deliberate misconduct by staff, this happens, but it would be unwise to generalize. In the context of La Merced, we see very clearly how lack of materiality and time determine the affective performance of staff towards residents, regardless of whether or not the former have a helpful and supportive attitude towards the latter. The possibilities for offering empathetic, 
compassionate and restorative care will be minimal if the material needs of the center and the staff are not met first: better salaries and more employment benefits, expanded and improved provision of medical supplies and infrastructures, increases in staffing numbers, and better staff training, etc. Therefore, in order to move towards a revolution in the ways in which care is provided, so that it is offered equitably while respecting the rights of both the residents and caregivers, it is essential that there is a transformation in the material, economic, political, and social structures and infrastructures through which this resource is offered.

\section{Bibliography:}

Agamben, G. (1998). Homo sacer: Sovereign power and bare life. Stanford: Stanford University Press.

Aguilar, C., Soronellas, M. y Alonso., N. (2017). "El cuidado desde el género y el parentesco: maridos e hijos cuidadores de adultos dependientes". Quaderns de l'Institut Catala d'Antropologia 22(2): 82-98.

Aulino, F. (2016). "Rituals of care for the elderly in Northern Thailand: merit, morality, and the everyday of long-term care. "American Ethnologist 43 (1): 91-102.

BIEH, l J. (2005). Vita: Life in a Zone of Social Abandonment. Berkeley: University of California Press.

-. (2012). "Care and Disregard". In A Companion to Moral Anthropology. Blackwell.

Blouin, C. (2018). La situación de la población adulta mayor en el Perú: Camino a una nueva política. Lima: Instituto de Democracia y Derechos Humanos de la Pontificia Universidad Católica del Perú.

BRIJNATH, B. (2014). Unforgotten: Love and the culture of dementia care in India. Oxford: Berghahn.

Buch, E. (2013). "Senses of Care: embodying inequality and sustaining personhood in the care of older adults in Chicago. American Ethnologist. 40:437-650.

-. (2015). "Anthropology of Aging and Care". Annual Review of Anthropology. 44: 277-293. 
Butler, J. (2009). Frames of War: When is Life Grievable? New York: Verso.

Comas D'Argemir, D. (2017). "El don y la reciprocidad tienen género: las bases morales de los cuidados". Quaderns de l'Institut Catala d'Antropologia 22(2): 17-32.

Congreso de la Republica del Peru (2016). Ley 30490. Ley de la Persona Adulta Mayor. Lima, 30 de junio de 2016. El Peruano, 21 de julio de 2016.<http:// www.leyes.congreso.gob.pe/Documentos/Leyes/30490.pdf>.

Foucault, M. (1976). The History of Sexuality. An Introduction. New York: Vintage Books.

Goethals, S, Dierckx de Casterlé, B. and Gastmans. Ch. (2013). "Nurses' ethical reasoning in cases of physical restraint in acute elderly care: a qualitative study". Medicine, Health Care, and Philosophy. 16: 983-991.

Goffman, E. (1961). Asylums. Essays on the Social Situation of Mental Patients and Other Inmates. New York: Anchor Books.

HAmers, J.P.H and A. R. Huizing. (200)5. "Why do we ue physical restraints in the elderly?". Zeitschrift fur Gerontologie und Geriatrie. 38: 19-25.

Han, C. (2018). "Precarity, Precariosness, and Vulnerability". Annual Review of Anthropology. 47:331-43

Hochschild, A. R. (2003). The Commercialization of Intimate Life. Berkeley: University of California Press.

Instituto Nacional de Estadística e Informática (INEI). (2018). Situación de la población adulta mayor: enero-febrero-marzo 2018. [Accessed January 23, 2019]. <https://www.inei.gob.pe/media/MenuRecursivo/ boletines/o1-informe-tecnico-no2_adulto_ene-feb_mar2018.pdf>.

Kleinman, A. (2008). "Catastrophe and Caregiving: The Failure of Medicine as an Art". The Lancet. 371: 22-23

-. (2009). "Caregiving: The odyssey of becoming more human". The Lancet 373 (9660): 292-293

Livingston, J. (2003). "Reconfiguring old age: elderly women and concerns over care in southeast Botswana". Medical Anthropology. 22(3): 205-31

Loвo, S. (1982). A House of My Own: Social Organization in the Squatter Settlements of Lima, Peru. Tucson: University of Arizona Press.

Matos, M. J. (1984). Desborde popular y crisis del estado: el nuevo rostro del Perú en la década de 1980. Lima: Instituto de Estudios Peruanos. 
Ministerio de la Mujer y Desarrollo Social (2006). Plan Nacional para las Personas Adultas Mayores 2006-2010. Lima: MINDES

Mol, A. (2010). The Logic of Care: Health and the Problem of Patient Choice. New York: Routledge.

OrTíz, D. (2013). "A Dignified Life: Getting Homeless senoirs off the streets of Lima". Peru this Week. Retrieved from <http://www.peruthisweek. com/blogs-dignified-life-getting-homeless-seniors-off-the-streetsof-lima-60128>.

$\emptyset_{\mathrm{ye}}$, Ch, JAcobsen, F.F. and Mekri. T.E. (2016). "Do organisational constraints explain the use of restrain? A comparative ethnographic study from three nursing homes in Norway". Journal ofClinical Nursing. 26: 1906-1916.

RAfieE, G. (2009). "Physical restraint use in nursing homes: A systematic review of two opposing views". Canadian Nursing Home 20(2): 16-22.

Roberts, E. (2012). God's Laboratory. Assiste Reproduction in the Andes. Berkeley: University of California Press.

SAARNIO, R. and Isola, A. (2010). "Nursing staff perceptions of the use of physical restraint in institutional care of older people in Finland". Journal of Clinical Nursing 19: 3197-3207.

Stevenson, L. (2014). Life Beside Itself. Imagining Care in the Canadian Artic. Berkeley: University of California University Press.

TAYlor, J. (2008). "On Recognition, Caring, and Dementia”. Medical Anthropology Quarterly. 22 (4): 313-335.

Zelizer, V. (2005). The Purchase of Intimacy. Princeton: Princeton University Press. 